\title{
Discovery of the Leeward Blindsnake, Antillotyphlops geotomus (Thomas, 1966), on St. Eustatius, Caribbean Netherlands
}

\author{
Tim van Wagensveld ${ }^{1 *}$, Sander van Staa ${ }^{1}$, and Roland Butôt ${ }^{2}$ \\ 'Reptile, Amphibian and Fish Conservation the Netherlands (RAVON), Nijmegen, The Netherlands. \\ ${ }^{2}$ Naturalis Biodiversity Center, Leiden, The Netherlands. \\ *Corresponding author (t.vanwagensveld@ravon.nl)
}

Edited by: S. Blair Hedges. Date of publication: 15 April 2020

Citation: van Wagensveld T, van Staa S, Butôt R (2020) Discovery of the Leeward Blindsnake, Antillotyphlops geotomus (Thomas, 1966), on St. Eustatius, Caribbean Netherlands. Caribbean Herpetology, 69, 1-3.

DOI: $10.31611 /$ ch.69

The Leeward Blindsnake (Antillotyphlops geotomus) is a near threatened species according to the IUCN Red list (Powell et al., 2016), and was known only to occur on Antigua, Barbuda, St. Kitts, and Nevis, where it is considered a native species (Thomas 1966). Here we report the discovery of A. geotomus on St. Eustatius, Caribbean Netherlands. We obtained a DNA sequence of the mitochondrial 16S rRNA gene from a specimen collected on St. Eustatius in 2018 using the primers 16Sar (5'-CGCCTGTTTATCAAAAACAT-3') and 16Sbr (5'-CCGGTCTGAACTCAGATCACGT-3') (Palumbi 1996). The sequence was deposited in Genbank (MT256921). Blast analysis of the sequence resulted in $100 \%$ and $99.8 \%$ identity to sequences in Genbank of A. geotomus from Nevis (KF993199) and Antigua (AF366789) respectively. A 98.5\% identity match was found with its nearest relative Antillotyphlops monastus (AF366708, KF993209). This species identification (A. geotomus) is consistent with the absence of pigment on the underside of the tail, a diagnostic trait of A. geotomus compared with A. monastus (Thomas 1966). The collected specimen had a total length of $125 \mathrm{~mm}$, although they are known to reach lengths of up to $213 \mathrm{~mm}$ (Hedges et al. 2014). Furthermore, St. Eustatius is geographically in close proximity to St. Kitts \& Nevis, which lie on the same shallow submarine bank only to be separated by the sea after the last ice age. Therefore, $A$. geotomus is likely native to St. Eustatius and not introduced. The other snake known from the island is the Red-bellied Racer (Alsophis rufiventris, native).

Three individuals of $A$. geotomus were observed in total, of which one specimen was collected (Fig. 1). The collected specimen has been preserved in ethanol and has been catalogued into the Naturalis Biodiversity Center collection in Leiden, The Netherlands (RMNH.5086842).
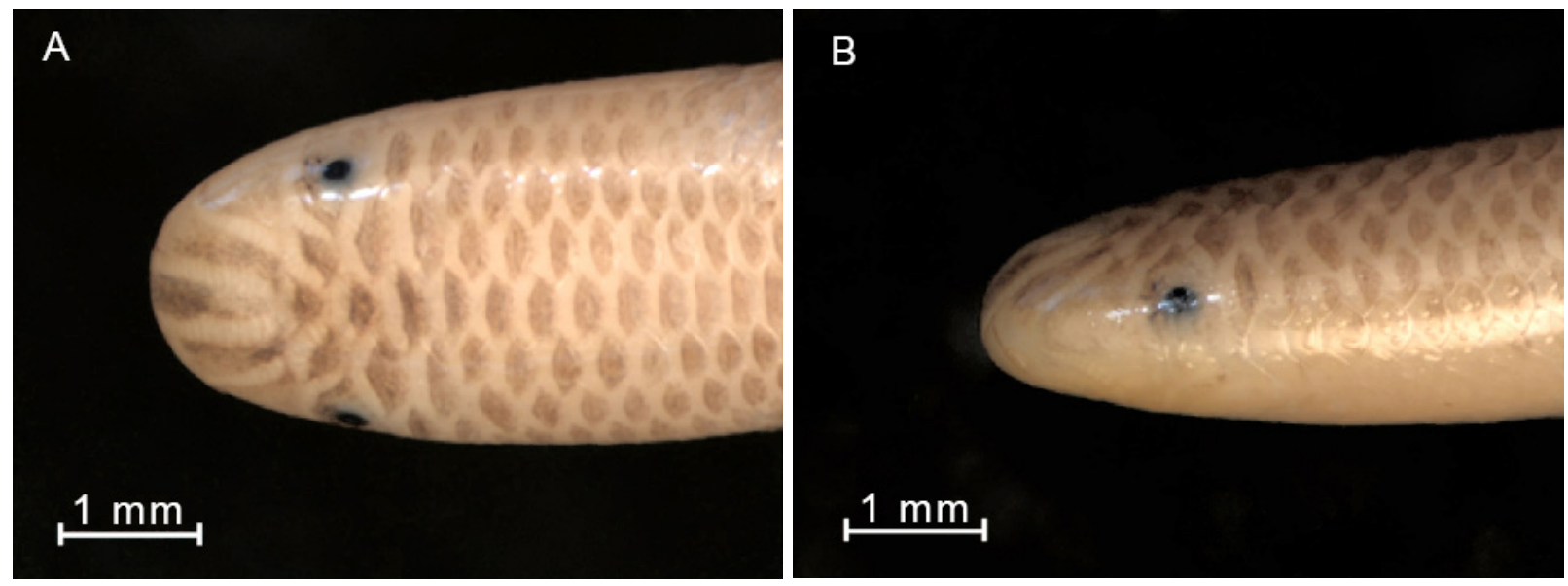

Figure 1. Dorsal (A) and lateral (B) head view from the collected specimen (RMNH.5086842). Photos: Roland Butôt. 
The first two specimens of Antillotyphlops geotomus were discovered in March 2017, lying next to one another, under the same rock, on the northern side at the foot of the Quill (a dormant volcano), at 78m elevation (17.481160,-62.950965; WGS 84). The third specimen was found and collected in November 2018, under a rock on the southern side of the Quill $(17.467331,-62.966736$; WGS 84) at 57m elevation. Upon exposure, all snakes attempted to quickly escape by tunneling into the ground. Both locations were characterized by a xeric environment, consisting mainly of larger trees, and sparse understory vegetation (Fig. 2).

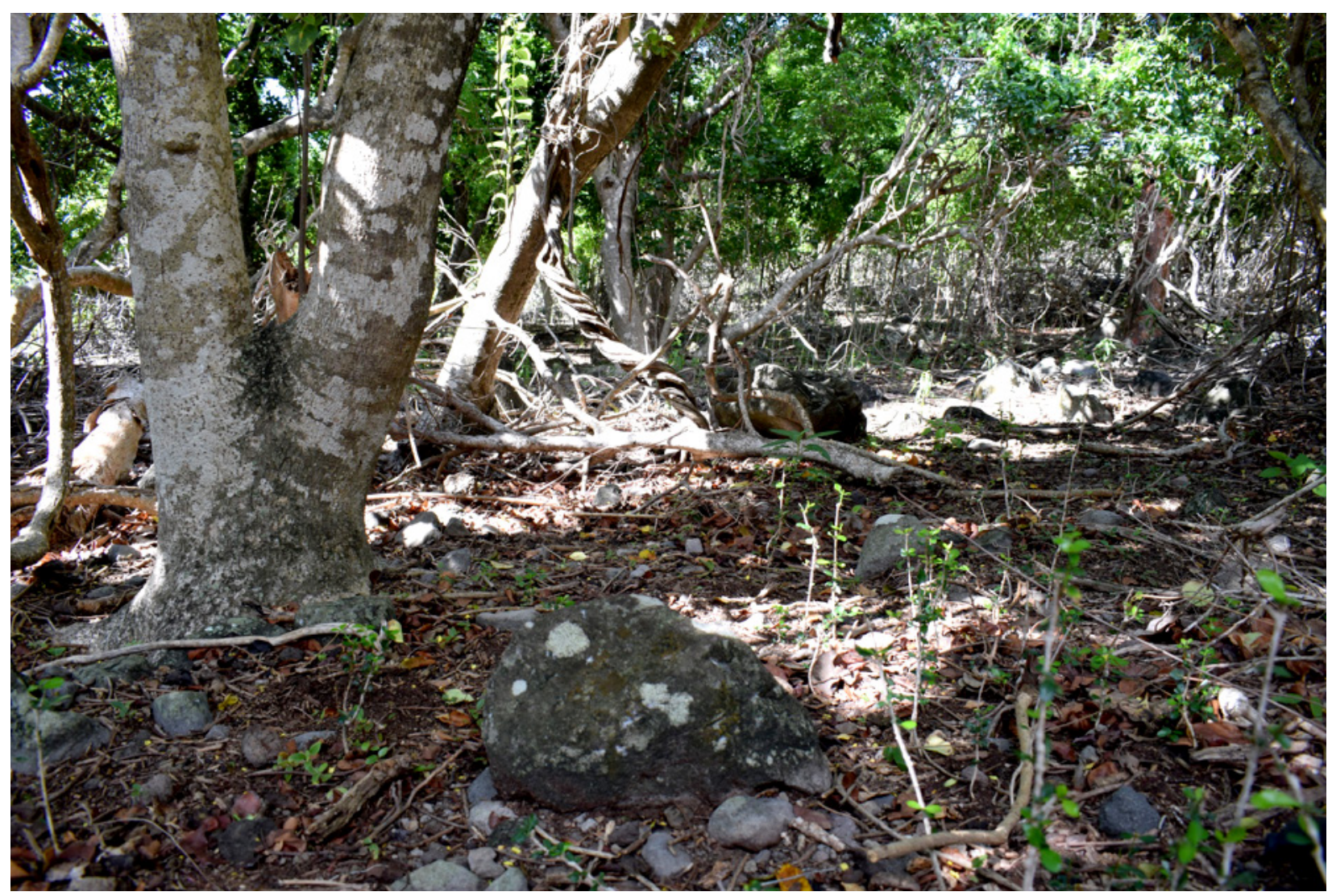

Figure 2. Location of the collected specimen from under the large rock in the foreground. The habitat is dry forest predominantly consisting of water mampoo trees (Pisonia subcordata) and several gumbo limbo trees (Bursera simaruba). The understory is almost completely denuded of vegetation with the exception of several species unpalatable for free roaming goats and cows on the island. Photo: Tim van Wagensveld.

The distribution of A. geotomus may be affected and/or limited within its range on St. Eustatius as vegetation composition is heavily determined by grazing pressure from roaming animals. The blindsnakes prey on insects (Henderson \& Powell 2009) that are likely associated with dry forests. Either the variety in, or lack of, vegetation may strongly differ across the island. Similar xeric forests, such as where the three snakes were observed, are limited to only a few areas around the base of the Quill, Signal Hill, and Boven National Park, and it is unknown whether $A$. geotomus presence also extends into the latter two areas. Further research is needed to get a better overview of the species distribution on St. Eustatius including search efforts in the more moist forests at higher altitudes in and around the Quill. It is unlikely that $A$. geotomus inhabits the landscapes in the islands' central 'Cultuurvlakte', which has little to no vegetation due to overgrazing.

The Brahminy Blindsnake (Indotyphlops braminus) is native to Asia (Hedges et al. 2014), but is introduced on St. Eustatius (Powell \& Henderson 2012). It is frequently sighted by local community members, in particular after rain spells. Their abundance may pose a competitive threat to the native $A$. geotomus, as the two species are ecologically similar. However, the impact of I. braminus on A. geotomus remains unclear, as no such study has been done. 
For future studies we recommend uncovering more on the distribution and natural history of $A$. geotomus, and whether the species is under competitive pressure from I. braminus. Also, obtaining DNA sequence data from additional genes may determine if there has been genetic differentiation among the islands occupied by A. geotomus.

\section{Acknowledgments}

We would like to thank the World Wildlife Fund of The Netherlands (WWF-NL), the International Union for the Conservation of Nature of The Netherlands (IUCN-NL), and Stichting Herpetofauna for their financial support, and St. Eustatius National Parks (STENAPA), Caribbean Netherlands Science Institute (CNSI), and Ton Kusters (HAS) for their help in the field. We also greatly appreciate S. Blair Hedges (Center for Biodiversity, Temple University, USA) for his assistance in identifying our collected specimen.

\section{References}

Hedges SB, Marion AB, Lipp KM, Marin J, Vidal N (2014) A taxonomic framework for typhlopid snakes from the Caribbean and other regions (Reptilia, Squamata). Caribbean Herpetology 49:1-61.

Henderson RW, Powell R (2009) Natural History of West Indian Reptiles and Amphibians. University Press of Florida, Gainesville, Florida, USA.

Palumbi SR (1996) Nucleic acids II: the polymerase chain reaction, pages 205-247. In: Hillis DM, Moritz C, Mable BK, editors, Molecular Systematics (Sinauer Associates, Sunderland, Massachusetts, USA.

Powell R, Henderson RW (2012) Island lists of West Indian amphibians and reptiles. Bulletin of the Florida Museum of Natural History, 51, 85-166.

Powell R, Daltry JC, Henderson RW (2016) Typhlops geotomus (errata version published in 2017). The IUCN Red List of Threatened Species, 2016, e.T75607290A115492504.

Thomas R (1966) Leeward Islands Typhlops (Reptilia, Serpentes). Proceedings of the Biological Society of Washington, 79, 255-266. 